politica, 38. årg. nr. 3 2006, 245-263

\title{
Clemens Stubbe Østergaard
}

\section{Kinas statslige globaliseringsstrategier: mod en kinesisk model?}

\begin{abstract}
Kinas globaliseringspraksis starter tidligt, er proaktiv og selektiv samt fastholder, men forvandler, statens rolle. Årsagerne kan belyses med en begrebsramme, der kombinerer agency og struktur i en analyse af de statslige responser. Der er otte vigtige kategorier af globaliseringsstrategier, især udviklet post-1992: handelsliberalisering og medlemskab af globale фkonomiske institutioner som Verdensbanken og IMF; særlig gunstig behandling af udenlandske investorer; smertefulde strukturreformer i stat og $\varnothing$ konomi; den trinvise internationalisering af det finansielle system, med langsom slækkelse af valutakontrol; udnyttelse af arbejdskraftreserven, men også opkvalificering og en internationalisering af opinion og embedsmænd; stærkt udbygget regionalt samarbejde styrker handelsliberalisering og $\emptyset$ vrig multilateralisme; investering i udlandet og opbygning af egne multinationale virksomheder (MNE); øvrig industripolitik inden for de snævre WTO-rammer. Med et klart blik for farer og mangler har Kina entydigt besluttet sig for, at globaliseringen er uomgængelig. Nationalt lærer man af den europæiske udgave af "konkurrencestaten”, på verdensplan arbejder man for ordensskabende global governance.
\end{abstract}

1993 var et vigtigt år for Kinas globalisering. Deng Xiaoping havde (gen)vundet magten året før og endelig fået flertal for at ændre den delvis reformerede statslige planøkonomi til helt markeds $\varnothing$ konomiske betingelser. Efter et års udmøntningsarbejde kom Centralkomitéens vidtrækkende beslutning med den støvede titel: "Om forskellige emner i opbygningen af et socialistisk markedsøkonomisk system." Samme år markerer skiftet blandt forskere fra "internationaliserings"- til globaliseringsdiskussioner, og en amerikansk politolog, Arif Dirlik, turnerede med forelæsninger om det hotte emne, mens bøger blev oversat, temanumre udgivet, og syvbindsværker redigeret. Det blev ikke ved snak: Kinas næststørste statsejede virksomhed, stålværket Shougang, købte jernminen Marcona i Peru for \$120 mio. og viste også interesse for at investere i opkøb af oliekilder, fiskeriproduktion og fødevareindustri (Gentelle, 1999: 57). Det er året, hvor Kina skelsættende blev nettoimportør af olie, og det er også året, hvor man samlede statens kraft ved at recentralisere en del af de kompetencer, der var lagt ud i firserne. ${ }^{1}$ I modsætning til de $\varnothing$ vrige systemer under behandling i dette temanummer har Kina ikke oplevet parti- eller regimeskifter eller befundet sig i en omfattende politisk transition eller nationsopbygningsfase. Derimod har den $\emptyset$ konomiske transition efter $1978 \mathrm{i}$ kombination med kun partielle politiske reformer været en afg $\varnothing$ rende forudsætning for vellykket globalisering (Østergaard, 2004).

\section{Hvad er det særlige eller det interessante ved} Kinas globaliseringspraksis - ud over resultaterne?

Allerførst er det bemærkelsesværdigt, hvor tidligt Kina er på banen i forhold til globalisering. ${ }^{2}$ Det anes i udenrigshandelsdebatten i 1975 (Fingar, 1980) og i 
Deng Xiaopings erkendelse først i 1980'erne af, at en ny form for global konkurrence, den økonomiske, var i færd med at blive vigtigere end den militære. Det fører til en tidlig globaliseret adfærd, en delvis overtagelse af neoliberale synspunkter (Liew, 2005) samt det, en forsker har kaldt "virtuel globalisering", nemlig globaliseret adfærd, $f \phi r$ en del af nøgleformerne for global økonomisk deltagelse er til stede. Der er en tydelig vilje til at skubbe Kina mod globalisering uden det ydre pres som bragte vestlige økonomier dertil.

Dernæst har ledelsen, støttet af tænketanke og rådgivere, typisk været proaktiv og selektiv i valget af globaliseringsstrategier. Det er sket på grundlag af stor opmærksomhed omkring de negative (men også de positive) følger for især et udviklingsland, samt med udgangspunkt $i$ en opfattelse af globalisering som en langstrakt proces, ikke en tilstand. En proces, som derfor kan påvirkes. Der er brugt mange kræfter på at analysere globaliseringens modsætningsfyldte karakter - snarere end på at tage stilling for eller imod den (Yu, 2004; Garrett, 2001; Moore, 2005). Der har været en debat mellem yderfløje, neoliberale og en ny venstrefløj (fx Zheng, 2004: 162-186). Men den brede mainstream af aktører har accepteret globaliseringen som en objektiv kendsgerning og en uomgængelig tendens i menneskelig udvikling. Samtidig har den fokus på $\phi k o n o m i s k ~ o g ~ i k k e$ kulturel eller politisk globalisering.

Det tredje forhold, som er værd at lægge mærke til, er, at ledelsen hidtil har formået at bevare den nødvendige autonomi internt og eksternt. I forhold til verdensøkonomien og dens stærkeste stater bidrager landets størrelse, med 22 pct. af verdens befolkning, naturligvis hertil, men det er ingen selvfølge, at man har kunnet fastholde statens rolle og øge dens kapacitet til at udforme indre og ydre globaliseringsstrategier. Internt har bureaukratier i et fragmenteret system kæmpet for deres interesser, men gradvis er erhvervslivet kommet direkte til med lobbyvirksomhed (Kennedy, 2005: 25). De statslige strategier har desuden været meget bredspektrede og indebåret store overvejelser om rækkefølge og hastighed (Palan og Abbott, 1996). Som vanligt for Kinas reformudvikling har de indebåret eksperimenter i mindre skala samt inkrementalisme. Resultaterne af alt dette ses i tabel 1, men kan opsummeres: Kina er nu verdens fjerde største $\emptyset$ konomi, tredje største handelsnation, andet største mål for investeret DFI og største indehaver af valutareserver.

Altså tidligt, proaktivt og selektivt samt med stærk statslig kapacitet og rolle. Hvordan skal disse særtræk ved Kinas globaliseringsstrategier forklares? En vigtig baggrundsfaktor for alle er eksistensen af et omfattende industrielt system efter 30 års opbygning samt tilstedeværelsen af omfattende organisatoriske ressourcer, dels historisk betingede, dels opbygget efter 1949 (Østergaard, 1995).

Det tidlige kan tilskrives flere forhold, men nok især ideer og identitet. For det første stod Kina i 1976 i en situation, hvor de ti foregående års kulturrevolution havde fjernet alle "velerhvervede interesser" og slettet al intellektuel aktivitet. Tavlen var visket ren, og de intellektuelle rådgivere og de tænketanke, som Deng oprettede, kunne starte uden mange forudopfattelser. Kina var også tvunget til at nytænke sin rolle efter et årtis erfaring med autarki og self-reliance. For det andet forekommer ideer vigtige. Idemæssige snarere end materielle kræfter til- 
Tabel 1. Globaliseringsrelevante resultatmål 1990-2005

\begin{tabular}{lcc}
\hline & $\mathbf{1 9 9 0}$ & $\mathbf{2 0 0 5}$ \\
\hline Nominelt BNP (mia. \$) & 388 & 2225 \\
BNP beregnet efter PPP (mia. \$) & 1145 & 9412 \\
Vækst (løbende 5 år) & 4,9 pct. & 13,2 pct. \\
Andel af globale BNP & 1,7 pct. & 5 pct. \\
Andel af globale BNP efter PPP & 6,1 pct. & 15,4 pct. \\
Urbaniseringsgrad & 27 pct. & 41 pct. \\
Pct. af BNP fra sektor: & & 12 pct. \\
Landbrug & 27 pct. & 47 pct. \\
Industri & 42 pct. & 40 pct. \\
Serviceindustri & 31 pct. & 843 \\
Eksport (mia. \$) & 68 & 38 pct. \\
Eksport i pct. af BNP & 17 pct. & 1082 \\
Anlægsinvesteringer (mia. \$) & 94 & 49 pct. \\
Anlægsinvestering i pct. af BNP & 24 pct. & 612 (2004) \\
DFI (mia. \$) & 198 & 16,6 pct. \\
Gennemsnitlige BNP-vækstrater & 1,6 pct. & 7,3 pct. \\
Regeringsindtægter i pct. of BNP & & (Indien 0,9 pct.) \\
Andel af global vareeksport & 10,8 pct. (1995) & \\
\hline
\end{tabular}

Kilder: Ahya et al. (2006: passim); Jiang (2005).

skyndede til globalisering - som i sig selv kan analyseres som ideologi (Strange, 2003: 6). Måske var globalisering også associeret med modernitet og alt det, Kina nu gerne omsider ville være medlem af - den identitet, det gerne ville indtage (Solinger, 2001). Endelig kan den tidlige globaliseringsstart være en sidegevinst ved de modige økonomiske reformer.

Det proaktive og selektive må forklares med udgangspunkt i beslutningstagerne, deres vigtigste rådgivere og den institutionelle kontekst. For at tage det sidste først har manglen på demokratiske processer givet en hurtigere beslutningsproces og bedre mulighed for konsistent, langsigtet og implementeret politik. Processen har også kunnet vægte nære sagkyndige rådgiveres indspil, og det kan ses som et led i den generelle professionalisering og specialisering i beslutningsprocessen (Lampton, 2001: 27). En særlig rolle tilfalder i den forbindelse professor Yu Keping, som nu er generalsekretær Hu Jintaos vigtigste rådgiver på globalisering, men som har været aktiv siden de tidlige 1990'ere. ${ }^{3}$ Endelig har en lille kreds af (utvivlsomt dialektisk opdragede) beslutningstagere personligt 
promoveret arbejdet med globaliseringsstrategier, det gælder fx Deng Xiaoping, Zhao Ziyang, Jiang Zemin, Zhu Rongji og Hu Jintao.

Den stærke statslige kapacitet og autonomi samt rollen omkring globaliseringsstrategi flyder først og fremmest af etpartistatens historiske og vedvarende bestræbelser på at bevare ledelsesmonopolet og nogle få, men effektive, leninistiske redskaber som nomenklaturasystemet. ${ }^{4}$ Men samtidig er der vilje til at transformere staten, blandt andet ved at reducere regeringsindblanding og dog bevare statens aktive rolle i visse områder, så man øger dens kapacitet til at påtage sig de nye opgaver, som en globaliseret markedsøkonomi indebærer. Her gælder det, at "alt må forandres, for at alt kan blive, som det er". Det kan også have indebåret en reformulering af klassealliancer for at bevare partiets uafhængighed af de samfundskræfter, der effektivt ville kunne stoppe reformudviklingen (Breslin, 2004). Samtidig betyder liberaliseringshegemoniet under globalisering, at der er behov for, at staten kompenserer de tabere, som ellers kunne true samfundets stabilitet.

\section{En analyseramme}

En egnet analyseramme kunne bygge videre på Prakash og Hart (2000a; 2000b), som analyserer statslige responser på globaliseringens trusler og muligheder. Modellen kombinerer betydningen af aktører og strukturer. ${ }^{5}$

1. Globale processer er de eksterne stimuli, som normalt påvirker aktører til at respondere med strategier, der kan håndtere "truslen" og påvirke fordelingen af omkostninger og fordele. Der er vindere og tabere inden for sektorer, firmaer og produktionsfaktorer, og de, der rammes, vil efter evne søge at moderere følgerne af globaliseringen. De globale processer kan dels være markedspresset, som fx kan føre til, at et land vælger "dyb integration"; det kan være internationale kræfter, som fx industrispecifikke protektionistiske handelsregimer a la multifiberaftalen (Moore, 2002); eller det kan være andre regeringers policypres, fx det amerikansk anførte pres - med WTO som én policymekanisme - for at fremme liberalisering og udbredelsen af principperne i the Washington Consensus.

2a. Den institutionelle kontekst er til dels et produkt af historien og indebærer en vis stiafhængighed. Den omfatter de gældende regler for policy-making og forholdet mellem regeringsinstitutioner. ${ }^{6}$ Selv om Kina har bevaret sit politiske system og en ganske høj statslig kapacitet, sker der løbende ændringer, som kan påvirke, hvor stærkt globaliseringen indvirker, og hvilke optioner regeringen har. Tilslutningen til WTO indebærer fx begrænsninger og det samme gælder opkomsten af virksomhedsfagforeninger. Her kan også medtænkes de sociale kontrakter eller historiske kompromiser, som kan konstateres, fx Mao-periodens "lav løn, men social tryghed", Deng-tidens "høj vækst, men polarisering" og senest den nye vægt på "bæredygtighed" og "det harmoniske samfund", dvs. kompensation af reform- (og globaliserings-)taberne (Wong, 2006).

2b. Den indenrigspolitiske dynamik skal indfange mobiliseringen af vinderkoalitioner til støtte for nye globaliseringsstrategier. De betinges blandt andet af den relative magt hos vindere og tabere samt de berørtes muligheder for at 
Figur 1. Analyseramme

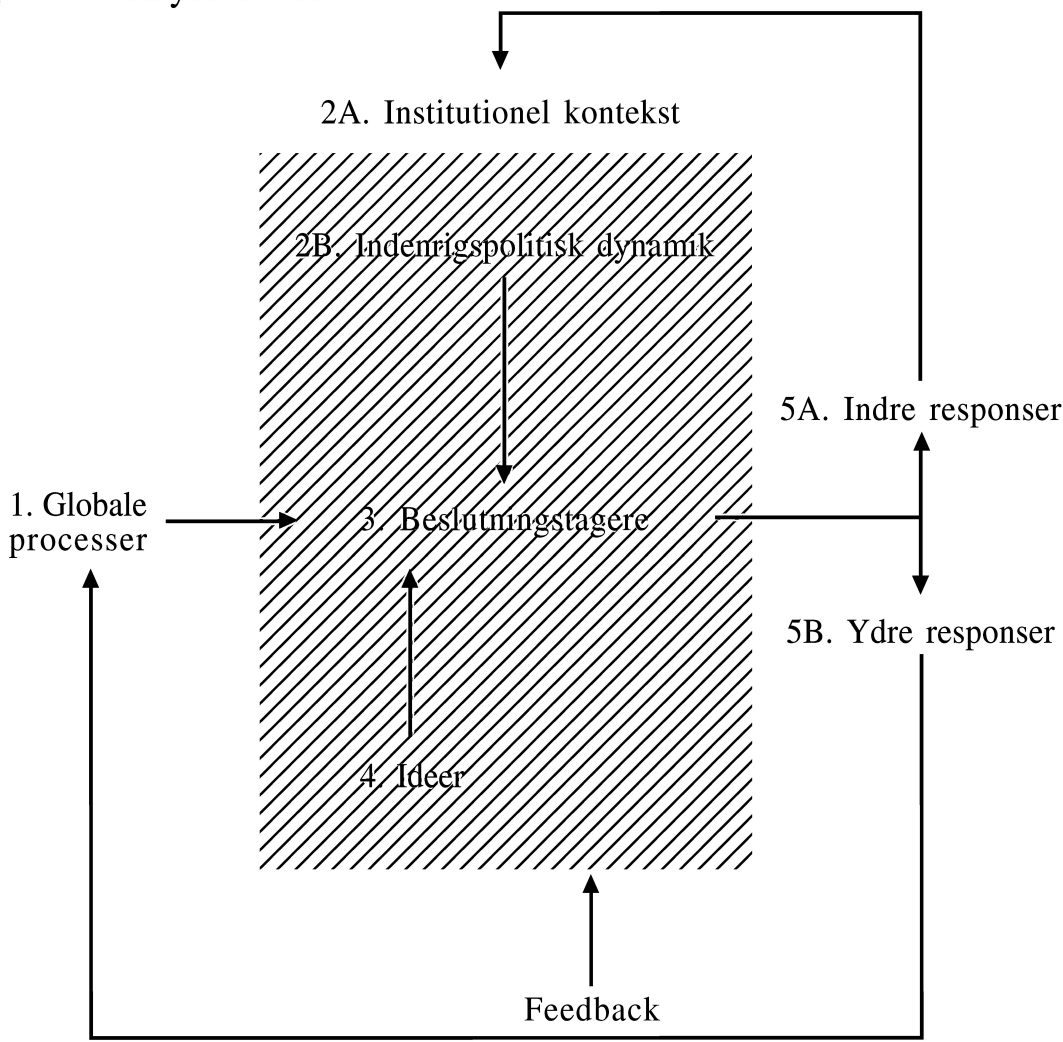

handle kollektivt. Interessegrupper og lobbyarbejde er nye ord i Kina (Kennedy, 2005; WSJ, 2006), men når globaliseringen svækker indgåede "aftaler", bliver interessegruppers opfattelser af omkostninger og fordele for medlemmerne et element i politik. Vigtige spillere i indenrigspolitikken om markedsintegration er først og fremmest forskellige bureaukratier (som dog kan ses som repræsentanter for sektorer, der taber og vinder), men også firmaer og deres sammenslutninger, NGO'er, udenlandske og transnationale interessegrupper, fx internationale organisationer samt andre regeringer.

3. De centrale beslutningstageres præferencer samt personlige og politiske ressourcer er stadig vigtige, om end de tiltagende indgår i en kollektiv beslutningsproces og i sidste ende er afhængige af accepten hos en bredere kreds, et selectorate i stedet for et electorate (en vælgerbefolkning). De er en form for koncernledelse og er lige så lidt eller meget "valgte" som de globale bankers ledelser. Deres forestillinger om Kinas identitet og ideelle rolle kan være vigtige, ${ }^{7}$ og under alle omstændigheder træffer de strategiske valg med lange konsekvenser. De kan vælge blandt de ydre pres for at fremme egne dagsordener, og kriser giver dem mulighed for at lave nye koalitioner. 
4. Ideer kan være både uafhængige, mellemkommende og afhængige variable i denne model. Som uafhængig variabel kan de være del af en diskurs, som via den globale medieindustri skaber ideer om ønskeligheden og effektiviteten af globalisering - også for andre end de MNE'er og industrilande, der har størst fordel. En neogramsciansk analyse ville pege på, at diskursen og informationsstrømme på tværs af grænser netop domineres af globaliseringens varmeste fortalere, MNE'er og finansfirmaer i industrilande, som med et kulturelt hegemoni producerer konsensus omkring bestemte ideer om henholdsvis markeders og regeringers roller, til fordel for "dyb integration" (Cox, 1996).

Som mellemkommende variabel findes ideer (og normer) hos beslutningstagerne, og ikke mindst i deres tænketanke, $\mathrm{i}$ form af fx forståelsen af globalisering som fænomen eller kausale overbevisninger, som forklarer, hvorfor globalisering er en udfordring, hvad der er følgerne af givne strategier osv. De påvirker derfor i samspil med interesser aktørernes præferencer blandt policyalternativer. Som afhængig variabel kan de genfindes, når Kina selv forsøger at etablere en diskurs eller en moddiskurs som led i sine statslige globaliseringsstrategier. Det ses fx i den tentative støtte til en alternativ Beijing Consensus og senest forsvaret for frihandel, mens andre tyer til protektionisme (Ramo, 2004).

5. Produktet, indre og ydre responser på globaliseringen, betragtes her som strategier, og de har en feedbackvirkning i modellen. Globaliseringen præger Kina, men Kina præger sandelig også globaliseringen. Strategier findes både på virksomheds- og regeringsniveau; her er de sidste interessante. De kan ligge på forskellige aggregeringsniveauer, fra subnationalt over nationalt til regionalt og globalt. De kan være rettet primært mod det ydre (internationale) miljø, mod det indre (nationale) miljø eller mod begge. De kan også opdeles efter, om de er globaliseringsfremmende eller er modtræk for at begrænse negative virkninger. De kan naturligvis variere fra sagområde til sagområde, og de vil ofte distribuere fordele og omkostninger asymmetrisk over aktørerne. Strategierne kan rumme forskelligt sigt (langt, mellem, kort), og deres rækkefølge og timing er i sig selv interessant. Der kan også sondres efter de midler, de indebærer: De kan være individuelle (nationale) eller indebære kollektiv handlen mellem nationer, være kompetitive eller samarbejdsprægede, ligesom de overvejende kan bygge på eksisterende institutioner eller indebære institutionel fornyelse. De kan endelig opdeles efter, hvilke typer globalisering de sigter på - det være sig økonomisk, politisk, kulturel, retslig etc.

Hvordan kommer alt dette til udtryk i Kinas globaliseringspraksis? ${ }^{8}$ Hvilke faktorer har siden 1991 som de vigtigste spillet ind på den kinesiske stats formulering og implementering af en globaliseringsorienteret politik? Her udvælges otte vigtige kategorier af statslige globaliseringsstrategier, især post-1991, idet 1980'erne dækkes godt i Howell (1993). Bagtæppet er reformpolitikken som helhed og den samtidige beslutning om helt at underordne udenrigspolitikken den vedtagne moderniseringspolitik (Moore, 2005). 


\section{Kinas globaliseringspraksis i otte punkter}

\section{1: Indmeldelse i de globale $\phi$ konomiske institutioner}

samt en omfattende handelsliberalisering

I tilbageblik må Deng Xiaopings ansøgning kort efter reformernes start i 1980 om kinesisk optagelse i Verdensbanken og Den internationale Valutafond ses som en tidlig globaliseringsstrategi. Den kom som et chok, skønt Kina var et aktivt FN-medlem fra 1971, men fulgtes op af medlemskab i Asian Development Bank og af ansøgningen til GATT i 1986, som endte med optagelse i efterfølgeren WTO i 2001 (Lu et al., 2003). Det hele placerer sig i den hastige udvikling fra næsten isolation til ligefrem "overinvolvering" i internationale organisationer set $\mathrm{i}$ forhold til Kinas udviklingsniveau (Johnston, 2003: 13). I 1977 var landet medlem af 21 IGO'er (international governmental organisations) og 71 INGO'er (international nongovernmental organisations). I 1997 var dette tal steget til 52 IGO'er og 1163 INGO'er (Lampton, 2001: 163). Samarbejdet betød sårbarhed over for sanktioner og krævede diplomatisk kapacitet, men gav, især for Verdensbankens vedkommende, meget stort udbytte, ikke mindst i form af ekspertrådgivning, som også kunne bruges indenrigspolitisk til at presse reformer igennem. Personaleudveksling med Verdensbankens hovedkvarter i Washington og med andre IGO'er - førte fx til "epistemiske fællesskaber" på tværs af landegrænser, som arbejdede for yderligere integration i verdens $\emptyset$ konomien. Kina blev den største modtager af udviklingsbistand fra Verdensbanken, og tonsvis af grundige, komparative rapporter var med til at ændre institutioner, påvirke ideer og forandre lederressourcer i Kina.

Samtidig fik Kina gennem deltagelse i talløse internationale regimer og grupperinger som G8 og G20 mulighed for at påvirke international udvikling. Det krævede, at man tilpassede indenlandske forhold og lovgivning til globale regimer, når der var sammenstød. Definerer man politisk globalisering som ændring af politisk praksis og institutionelle strukturer for at tilpasse sig, så er Kina også med her. Landet har bidt tænderne sammen og underskrevet mængder af aftaler fra sikkerhed over handel og miljø til menneskerettigheder. Spørgsmålet er dog fortsat, om formel tilpasning også fører til reel overbevisning. Satsningen på multilateralisme handler også om at påvirke konteksten for globalisering i retning af governance from the top. Ja, man kan spørge, om et af Kinas strategiske modtræk (over for amerikansk hegemoni i globaliseringsepoken) ikke er at bygge på formelle og uformelle interdependensmekanismer, herunder den institutionaliserede multilateralisme - i fx frihandelsaftaler - som globaliseringen lægger op til både på det regionale og globale niveau?

Med "Den åbne dørs politik" og reformerne i øvrigt gjaldt det om at blive globalt konkurrencedygtig. Man igangsatte derfor en stor handelsliberalisering og fratog de mægtige statshandelskorporationer deres monopoler, så udenrigshandlen privatiseredes. Liberaliseringen indebar en stærk unilateral reduktion af toldsatser igennem 1990'erne, og de WTO-vilkår, Kina endte med at acceptere, er overordentlig vidtgående. 


\section{Sarligt favorable forhold for udenlandske investeringer}

En særdeles vigtig del af Kinas globaliseringsstrategi har fra første færd været den sarlig favorable behandling af udenlandske investorer. Sammen med handelsliberaliseringen er det en vigtig vej ind i den internationale arbejdsdeling. Politikken er kaldt "segmenteret deregulering": Man begyndte nogle få steder ${ }^{9}$ og gav investorer store privilegier i afgrænsede zoner. De oversøiske kinesere opdagede som de første den billige, kvalificerede arbejdskraft og havde forbindelserne til lokalstyrerne - i 1993 var der 8.000 zoner. ${ }^{10}$ Med succesen blev de "magneter", hvor kinesiske virksomheder prøver at flytte ind for at internationalisere og få teknologifordele.

Landets størrelse og bevarelsen af de lokale ledelsers incitamenter til vækst gør, at der let opstår konkurrence mellem temmelig ens lokale regeringer om at skabe det bedste investeringsklima. Det er spontant og en "uorganiseret kollektiv handlen" med en vis omgåelse af centrets institutionelle begrænsninger, en konkurrence på mange parametre som skat, infrastruktur, bureaukratireduktion, service etc.; samtidig er der et ydre pres, dels fra de konkret interesserede internationale aktører, dels i løbet af WTO-forhandlingerne (Lampton, 2001: 178). Der er oplagt fare for et race to the bottom, faciliteret af lokale bureaukraters lukrative gatekeeper-positioner og i sidste ende en national undertrykkelse af arbejdskraften i en periferi-fordisme, bifaldet af indflydelsesrige forskere. Strejkeretten blev afskaffet ved forfatningsændringen i 1982, hvad der dog ikke forhindrer op mod 100.000 aktioner om året også mod udenlandske og især koreanske og kinesiske arbejdsgivere.

Men udbyttet af denne strategi er stort, og i dag er der udenlandske penge i en halv million virksomheder (Jiang, 2005). Allerede i 1997 stod direkte udenlandske investeringer for 145.000 virksomheder med 17,5 millioner ansatte, der producerede 14 pct. af industrioutput, 12 pct. af skatteindtægterne og 47 pct. af udenrigshandlen. 300 af verdens 500 største multinationale selskaber var repræsenteret. Øvelsen gik på at få investorer med teknologi til Kina og så håbe på, at partnerskaber og gradvis diffusion ville få Kina med i den globale "teknologimarch". En vurdering er, at det er lykkedes på grund af den kinesiske regerings relativt stærke forhandlingsposition, betinget af markedets størrelse, muligheden for at dele og herske $\mathrm{i}$ forhold til de mange interesserede samt bevarelsen af en stærk statslig position i industrier med store køb hos MNE'er (Yang og Su, 2000: 57). Samtidig udgjorde den udenlandske kapital kun få pct. af de samlede investeringer, og eksportafhængigheden lå på 4,6 pct. mod et globalt gennemsnit på 14,6 pct. (Hu, 2001: 3).

Nu hvor det nok så meget er hi-tech snarere end arbejdsintensiv virksomhed, de multinationale selskaber er interesserede i, er der mindre tiltrækning ved et race to the bottom på arbejdskraft, miljø og sikkerhed end almindelig antaget. Derfor skal man finde på nye måder at tiltrække videns- og teknologiintensive investeringer på. Investorerne vil gerne have politisk stabilitet og stabil politik, mens transparens er mindre afgørende. Kina er forudsigeligt og stabilt for investorer, og det giver pote. Samtidig er staten stor og autonom nok til ikke at lade sig bruge i global krigsførelse mellem MNE’er (Prakash og Hart, 2000b: 268). 


\section{Indenlandske omstruktureringer og}

statens transformationsproces $i$ 1990'erne

I løbet af firserne havde Deng "købt politisk støtte" til sit økonomiske reformprogram ved at decentralisere megen myndighed til provinserne og deres vigtige ledere. Det fik den uheldige virkning, at Beijings ledelse af økonomien efterhånden var som at "styre et hangarskib med roret til en jolle". Hvis man ønskede en globaliseringsdygtig "regulerende stat", måtte magten recentraliseres, så roret blev større. Det blev den først via de store skattereformer i 1993 og 2002, som sikrede centralmagten stigende del i skatteindtægterne og dermed et bedre grundlag for makroøkonomisk styring. Derpå kom en stor reform af centralbanken 1998-1999, så også den blev fjernet fra "den lokale indblandings forbandelse". Dermed blev det muligt at føre pengepolitik og have et reelt opsyn med den besværlige finanssektor. Endelig blev de mange regulerende instanser, som en markedsøkonomi skal bruge, også udbygget i løbet af 1990'erne. Det var fx omkring patenter, copyright, varemærkning, miljø, kvalitet, standarder, forbrugerrettigheder etc. (Yang, 2004: 132). Alt dette var et led i ombygningen af det gamle leninistiske statsapparat til et, der er markedsegnet, men stadig effektivt over for globaliseringens krav.

Makroøkonomisk styring på globaliseringens oprørte hav kræver også en stærk, veltrimmet og autonom central ledelse. Den blev etableret ved 1998-reformen, som gjorde SETC (State Economic and Trade Commission)/SDPC (State Development Planning Commission) samt Finansministeriet og centralbanken til de vigtigste institutioner, der skulle "holde den samlede balance, tæmme inflationen og optimere den økonomiske struktur", som det hed (Yang, 2004: 41). Under $\emptyset$ konomiprofessor Zhu Rongjis tid som regeringschef (1998-2003) blev plan$\emptyset$ konomiens industriministerier nedlagt og regulerende myndigheder opgraderet. Med omfattende nedskæringer, privatisering og outsourcing svandt staten ind, men har beholdt mange erhvervsmæssige "trumfkort" og forbliver den dominerende spiller i nogle vigtige sektorer. For yderligere at trimme den og gøre den til en moderne reguleringsstat, som på armslængde kan lægge rammerne for $\emptyset$ konomien, blev regeringsorganer, domstole, militær etc. mellem 1998 og 2001 tvunget til at afgive de uendeligt mange virksomheder, som man, nærmest ved knopskydning, var blevet ejere af. Kampagnen forløb i tandem med bekæmpelse af smugleri og korruption.

Mange af disse strukturreformer krævede opfølgning i 2002-2005, men resultatet af denne store klynge af reformpolitikker er øget statslig kapacitet, autonomi og konkurrencedygtighed. Det har været strukturreformer med omfattende fyringer - alene i den statsejede industri en reduktion med 45 millioner, og en halvering af statsapparatet - og disse store programmer har krævet politisk støtte fra koalitioner, som kunne overvinde den ganske store uvilje fra grupper, der tabte. Men med gennemførelsen af dem står man stærkere som markedsøkonomi og reguleringsstat, også i forhold til planlægning og gennemførelse af globaliseringsstrategier. Man bemærker, at Kina i World Competitiveness Yearbook 2005 nu ligger nummer 19 på konkurrencedygtighed og nummer 17 globalt på regeringseffektivitet (Qin, 2006). Staten er således en integreret del af 
Kinas globaliseringsproces, den er svækket i nogle områder, styrket eller konsolideret $\mathrm{i}$ andre. Den har lånt af det globale pres til brug for sin egen transformering og modernisering, så man kan sige, at de ydre globaliseringsprocesser har givet de kinesiske beslutningstagere bedre muligheder for at omskabe statssystemet til at akkommodere, skabe rammer for samt styre markedet (Zheng, 2004: 18). ${ }^{11}$

\section{De vanskelige strategier på finans-, kapital- og valutaområdet}

En af de største udfordringer er forbindelsen mellem Kinas finansielle system og den globale økonomi. Nolan (2001: 49) sammenligner Kinas deltagelse med en båd, der står til havs. Der er to vigtige spørgsmål: Hvordan er vejret, og hvor godt er båden bygget? Vejret bliver med stor sandsynlighed dårligt, kapitalstrømme er meget destabiliserende i dagens spekulationsprægede verden, og båden er ikke nær så stor eller stærk som dem, verdens ledende finansvirksomheder sejler i. Finansiel integration, globaliseringen af finansmarkeder siden 1980'erne, er globaliseringens kerne (Palan og Abbott, 1996: 22), men Kinas banker kommer fra en fortid med politisk bestemt långivning og skal lære forretningsmæssig drift og risikostyring. Kampen i 1996-1998 for at ændre centralbanksystemet, dets opsyn med bankerne samt reguleringen af værdipapir- og forsikringsindustrier var et vigtigt første skridt, som blev fulgt af store prikkerunder i bankerne. Kina har nu gennemført opbygningen af en moderne banksektor med tidssvarende regelsæt, men afviklingen af misligholdte lån tynger, og der er ikke fundet en løsning på statens ejerskab i de fire hovedbanker (Fung og Zhang, 2002: 51). Mod slutningen af 2006 åbner WTO-reglerne Kinas marked op for de store udenlandske rivaler. De er giganter som Citigroup, Deutsche Bank og Mizuho Group, hver af dem mange gange større end Kinas banker tilsammen, og deres udtalte mål er at penetrere udviklingslandenes finansmarkeder. Det er i den forbindelse svært at vurdere, om man er nået langt nok med reformer af det finansielle system til ikke at blive "overtaget". Disse reformer har mange tabere blandt virksomheder og lokale myndigheder, og samtidig skræmmer sporene fra Koreas liberalisering.

Ser man fx på den asiatiske finanskrise i 1997-1998, klarede Kina sig godt. Det skyldes, at man ikke havde indført fuld omsættelighed af valutaen, men bevaret kontrol med betalingsbalancens kapitalposter, samt at man allerede da besad store valutareserver (de er nu \$1.000 milliarder og med til at dække USA's stigende gæld). Kina har altid været forsigtig med at ændre på sit valutaregime på grund af det finansielle systems svagheder, truslen om destabilisering og virkningen for beskæftigelsen. Man vil for alt i verden ikke slippe kortsigtet, spekulativ kapital ind og risikere en "kinesisk finanskrise". Men i 1994 gennemførtes en stor trinvis reform af valutasystemet, hvor der fra 1996-1997 blev gennemført fuld konvertibilitet af yuan'en på betalingsbalancens lфbende poster; i praksis blev den fast knyttet til dollaren. Man modstod fristelsen til at devaluere under finanskrisen, men har siden juli 2005 for første gang revalueret med efterhånden 3,7 pct. i forhold til dollaren. Kina kan kun gå gradvist frem, for der mangler en del forudsætninger for at lade kursen flyde, blandt andet risikostyringsevner, rentemarkedets udvikling og risikoafdæknings-instrumenter og -markeder. Kina fik jo 
først børser fra 1990-1991, og værdipapirmarkedet er underudviklet (Ahya, 2006: 62). Men med Hong Kongs lange erfaring som finanscenter og Shanghai under opbygning som efterfølger kan man roligt sige, at der arbejdes på sagen.

Opsummerende er der foregået en omfattende internationalisering af det finansielle system, en selektiv slækkelse af kapitalkontroller samt en lang inkremental valutareform. Denne proces fortsætter.

\section{Opmarksomheden på de menneskelige ressourcers betydning}

Demografisk er Kina i en overordentlig gunstig situation fra 1975 til 2010. Perioden udgør ét langt fald i forholdet mellem den arbejdende og ikke-arbejdende befolkning. Den billige og rigelige, men også velkvalificerede og sunde, arbejdskraftreserve fra landet fik uofficielt lov til at bryde med bopælsbindingen (hukou) og blive "flydende befolkning" eller fremmedarbejdere i eget land. For arbejdskraften som helhed betød det et tab af privilegier i stor stil, så meget værre som man har forladt de socialistiske institutioner, men endnu ikke har etableret en erstatning for dem i form af en ny institutionel infrastruktur, fx et velfærdssystem, kollektive arbejdsmarkedsforhandlinger for alle, velfungerende domstole etc. For den flydende befolkning og de mange arbejdsløse står det værre til. De er andenklasses borgere eller slet ikke borgere. Solinger (2001) ser et paradoks i, at statens anstrengelser for at komme med i det globale samfund indebærer reel eksklusion af mange i det nationale samfund. Disse grupper har med strejkerettens afskaffelse i 1982 - og 1994-loven, som endelig muliggjorde fyring af arbejdere - ikke haft nogen gennemslagskraft over for beslutningstagerne.

I den modsatte ende af spektret har det Kommunistiske parti koopteret den nye $\emptyset$ konomiske elite ind i partiet. Dermed blev de nyrige kapitalister legitimeret, og vejen til ledende poster i partiet ligger åben. Kina har som bekendt en del milliardærer, og der har udviklet sig en delvis lobbybaseret symbiose mellem den politiske og økonomiske elite.

Mindre kontroversielt har Kina længe arbejdet på at blive bedre til at tappe en virkelig stor globaliseringsressource: dets hjernekraft. Med David Lamptons ord er det ikke den militære udfordring, vi skal frygte fra Kina, men den intellektuelle. Uddannelsespolitisk har man siden de tidlige 1980'ere søgt at fremme en global indstilling, dels via engelskundervisning og internettet med Kinas 125 millioner brugere, dels via dets hundredetusinder af studerende i udlandet og de stadig flere udenlandske studerende i Kina (Zweig, 2002).

Personalemæssigt i staten, såvel på nationalt som lokalt plan, ansættes, forfremmes og videreuddannes de mest globaliseringsorienterede ved hjælp af de nomenklaturamuligheder, partiet fortsat har. Opinionen som helhed er globaliseringsvenlig. Intellektuel debat og opinionsundersøgelser afspejler en stor internationalisering: Et amerikansk-kinesisk survey i seks storbyer fandt, at 90 pct. af de adspurgte mente, at globalisering er godt for Kinas økonomi, og 76 pct. svarede, at det er godt for Kina. Tallene ligger højt over de tilsvarende amerikanske.

Det er svært at sige, hvor den umiskendeligt stærke offentlige opinion for globalisering kommer fra, men den giver regeringen stor handlefrihed. Samtidig eksisterer den side om side med stolthed over egen fortid og præstationer, men 
uden megen mistro eller fremmedfjendtlighed, som ville ramme udenlandske investorer. Måske er der en sammenhæng med de 50 millioner oversøiske kinesere, som altid har udgjort et internationaliserende element for moderlandet, og som tegner sig for en halvpart af de direkte investeringer. Kontrasten til Japan er betydelig: Før internet og globalisering fungerede Japans etnocentriske kultur fint, men den har været ude af stand til at følge med siden.

\section{Regionalisme som strategi over for globalisering}

Regionalt samarbejde kan afværge nogle af de negative aspekter af globalisering. Det kan være den kontekst, inden for hvilken effektiv regulering og institutionsbygning finder sted. Det kan også styrke medlemmernes forhandlingsposition i globale multilaterale forhandlinger, fx om regler for det internationale økonomiske system. Kinesiske beslutningstagere blev fra starten af 1990'erne mere varme på multilateralt samarbejde i Asien. Kina så Østasien som "uorganiseret" i forhold til Europa og Nordamerika og greb til frihandelsaftaler, i første omgang med Hong Kong (CEPA), så med ASEAN-landene i Sydøstasien som den letteste vej til et samarbejde, der i en kaskadestrategi gradvis kunne omfatte hele Østasien og samtidig var en styrkelse af handelsliberaliseringsstrategien (Cai, 2004). Finanskrisen i Asien flyttede dramatisk på Kinas syn på institutionaliseret regionalt samarbejde. Derefter gik det endnu hurtigere: Ideen om et frihandelsområde omfattende Kina og ASEAN dukker op på det tredje APT-topmøde i Manila i 1999. ASEAN havde indset sine økonomiers sårbarhed, og Kina sin afhængighed af stabilitet og velstand i regionen. På basis af en ekspertgrupperapport offentliggør Brunei-topmødet i 2001 beslutningen, en rammeaftale underskrives i 2002, og forhandlinger afsluttes i 2004 efter Kinas tilbud om "en tidlig høst", nemlig ensidige toldnedsættelser på landbrugsprodukter fra ASEAN og fra juli 2005 på 7.000 varer. I landets indenrigspolitiske dynamik har landbrugssektoren og dens bureaukratier ikke stor vægt. I et demokrati ville dens $60+$ pct. af befolkningen have stoppet disse indrømmelser og reformerne med. Til gengæld har rådgivere og tænketanke bag beslutningstagerne stærkt promoveret ideer om regionalisme (Zhang, 2004). "The Pan Asia Trade Pact" træder i kraft i 2010, og ud over at være verdens største frihandelszone (1,7 milliarder mennesker, BNP over \$2 trilliarder) omfatter den også militært samarbejde, internetsikkerhed, epidemivarsling og ikke mindst et stort infrastrukturprogram. Samarbejdet med ASEAN suppleres med den slagkraftige Shanghai Cooperation Organisation (SCO) med Rusland og de centralasiatiske lande.

Regionalisme er en måde at bruge tilvejebragt "størrelse" til at opnå en bedre position globalt. Det kan ses som en del af globalisering og fremmes af de samme faktorer. Men det er jo også, i nogle scenarier, ligefrem et alternativ, hvis globaliseringen kollapser som følge af protektionisme i industrilandene. Doha-rundens nylige sammenbrud, som følge af amerikanske og til dels europæiske strategier, aktualiserer dette aspekt (Jacques, 2006). Situationen kan være ved at vende, så USA og industrilandene går væk fra den globale vision, mens Kina forsøger at holde dem fast på den - nøjagtig som USA gjorde med Storbritannien for 100 år siden. 


\section{Opbygning og styrkelse af egne multinationale virksomheder}

Peter Nolan (2001) har undersøgt, hvordan Kina med en bred industripolitik siden 1980'erne har forsøgt at fostre en gruppe af store moderne koncerner, som kan konkurrere med verdens ledende virksomheder, i en tilpasning til globaliseringen. Altså et "nationalt team" af de 30-50 bedste statsvirksomheder. I 1987 kom det første policy-dokument om mål og midler i udviklingen af "virksomhedsgrupper". En bruttogruppe på 120 af de mest overskudsgivende virksomheder, i strategisk vigtige sektorer, med gennemsnitligt 60.000 ansatte, blev udvalgt af Statsrådet i 1991 og 1997, beskyttet med toldsatser, givet særlige rettigheder og børsnotering (Yang, 2004: 33). Japan havde haft succes med dette, og efter 30 år havde de sidst i 1980'erne 20 af de 100 største firmaer i Fortune 500s rangliste over de multinationale. Efter 15 år har Kina stadig langt igen, og årsagen må overvejende søges i højindkomstlandenes, især USA's, samtidige big business revolution med udvikling af gigantiske oligopoler via de store fusioner i 1990'erne. De har nu enorme markedsandele og dominerer globale netværk. Via WTO, TRIPS og andre aftaler har de skabt en såkaldt level global playing field (hvor nogle spillere ganske vist er fire meter høje, andre en meter), som gør det langt sværere end for ti år siden at lave virksomheder i ulande, som kan konkurrere. ${ }^{12}$

Samtidig er Kina blevet særdeles aktiv i den Go Out-politik, som begyndte i 1993, og som støtter landets egne direkte udenlandske investeringer - nu omkring \$50 mia. - dels efter nye markeder, dels efter ressourcer herunder olie og fødevarer, dels efter teknologisk og managementfornyelse (Zhang, 2005). Det indebærer omfattende opkøb af divisioner af multinationale selskaber for på den måde at internationalisere kinesiske virksomheder og søge opad i de globale industrielle værdikæder.

\section{8. Øvrig industripolitik ...}

Med WTO-aftalen afskrev Kina sig næsten alle de mekanismer, der de sidste 200 år har udgjort industripolitikkens kerne for en række lande, der har fostret store virksomheder. Traditionel industripolitik gik ud på at beskytte endnu ukompetitive industrier, fx med told, kvoter, eksportsubsidier, mens den østasiatiske udviklingsstatsmodel handlede om selektive indgreb for at fremme de konkurrencedygtige industrier, $\mathrm{fx}$ ved at styre investeringskapital de rigtige steder hen. Men som ejer har den kinesiske stat desværre været utrolig god til at tilgive dårlige præstationer. Staten er godt nok autonom, men den noget partikularistiske måde, den har relateret sig til industrien på, har bevirket, at bureaukrater ofte fulgte snævre interesser snarere end nationale mål (Moore, 2002: 284). Beijings evne til at føre strategisk industripolitik er således begrænset, men det er jo også en slags globaliseringsstrategi at lade producenterne mærke verdensmarkedskræfternes effekt direkte. Den historisk kontingente institutionelle kontekst, dvs. statens organisering og kapacitet (fx dens fragmenterede og forhandlingsprægede natur og manglen på en "lods"-instans som Japans MITI) og de paternalistiske policy-netværk, er fortsat institutionel kultur i regeringsindustrirelationerne. Det er og bliver - sammen med virkningen af globaliseringsprocesser udefra - en vigtig hindring for at gennemføre en udviklingsstatsstrategi. Statsrådets vedta- 
gelse i marts 1989 af en ny ramme for industripolitik og i juni 1994 med "The framework of national industrial policy for the 1990s", som er meget interventionistisk, blandt andet over for bilindustrien, viser forsøg og tro på, at man kan lave en "Østasiatisk model". Denne tro kan ligge bag afvisningen samme år af de samme skrappe vilkår for WTO-medlemskab, som man fem år senere affandt sig med.

Fors $\varnothing$ get blev foreløbigt opgivet til fordel for markedsudvidende politikker, en administrativ deregulering, som blandt andet kunne få støtte, fordi industribureaukrater erkendte vanskeligheden ved midt $\mathrm{i}$ en $\emptyset$ konomisk transition fra planøkonomi til marked at udvikle tilstrækkelig sagkyndig "administrativ vejledning". Alt flød bogstaveligt talt: med nyfødte markedsinstitutioner, udefinerede ejendomsrettigheder, decentralisering-recentralisering, korruptionsfristelser og kriser. Dalende administrativ sammenhængskraft og strammere ressourcer gjorde det også svært effektivt at implementere en statsledet strategi (Moore, 2002: 290).

Det betyder ikke, at industripolitik er afskrevet i al fremtid. Hvor Centralkomitéens Virksomhedsarbejde Komité i 2000 kontrollerede 180 af de vigtigste firmaer, blev der med strukturreformer i 2003 lagt større afstand - under en filosofi om at opnå regulatorisk neutralitet, så myndigheder har et overopsyn, men ikke mere griber ind i daglig drift. Dermed kunne en udviklingsstatmodel blive mere realistisk. Samtidig er State Development and Reform Commission begyndt at tegne sig som den makroøkonomisk styrende og implementerende nøgleinstitution, der har manglet. Statens kapacitet er med andre ord under genopbygning (Yang, 2004: 59). Det er også nødvendigt, hvis der skal laves en målrettet selektiv industripolitik - inden for de rammer, WTO sætter - især for at sikre forskning og udvikling samt bekæmpe multinationale selskabers uhæmmede penetrering af den kinesiske $\emptyset$ konomi. Samtidig sætter det stigende ressourcebehov, herunder oliepolitikken, samt Kinas tiltagende brug af bistandspolitik som globaliseringsstrategi nye opgaver for staten i økonomien.

\section{Hvilke mangler og problemer truer fremtiden?}

Det skulle være fremgået undervejs, at der er mange farer og problemer i sejladsen på det oprørte og lumske hav, som globaliseringen udgør. En varm globaliseringsfortaler fremdrager blandt negative effekter, som skal modarbejdes, især tre: For det første trues den økonomiske sikkerhed, hvis udenlandsk kapital får kontrol med nøglesektorer, hvis udlandsgælden bliver for stor, eller finanssektoren for svækket; for det andet kan den nationale suverænitet svækkes og dermed muligheden for fortsat at udforme og gennemføre globaliseringsstrategier; for det tredje kan politiske værdier og kultur være i fare, og derfor må de traditionelle kulturelle værdier støttes, alt imens opmærksomheden skærpes over for eksport af især amerikaniserende elementer i globaliseringen, Kina må "nægte at overtage vestlige politiske systemer og centrale politiske værdier" (Yu, 2004: 2). Staten påvirker globalisering, men den påvirkes også deraf, dels i sine policypositioner, dels i sin ydre adfærd. Ikke alene påvirkes omkostningerne ved forskellige optioner, men også de institutioner, som staten kan ty til, forandres. Som 
interdependensen bliver højere, redigeres der tilmed i statens interesser. Selve grundlaget, det omgivende samfund, den socioøkonomiske struktur, påvirkes så stærkt af globalisering, at der er løbende behov for statslig opmærksomhed, hvis den politiske stabilitet skal fastholdes undervejs.

Blandt de mange problemer, som tegner sig for styrmændene samt deres rådgivere og navigatører, kan fire fremdrages her. For det første er det kinesiske hjemmemarked fortsat for lille. Det øger sårbarheden og afhængigheden af især den amerikanske $\varnothing$ konomis tilstand. Det er også lettere for virksomheder at globalisere, hvis man har succes på hjemmemarkedet. Det er lille, fordi lønnen er lav, opsparingen er særdeles høj, og det skyldes især manglen på et socialt sikkerhedsnet. Derfor vil fx udbredelsen af sygesikring, pensions- eller arbejdsløshedsforsikring virke, og det vil samtidig være en måde at kanalisere risici ved globaliseringsprocessen. For det andet har den skæve udvikling, som globaliseringen fremmer (Wan et al., 2004), givet Kina et polariseringsproblem: Indkomstuligheden stiger fra 1984 - hvor man går i gang med de reformer, der skulle gøre det muligt at deltage i globaliseringen - og forskelle mellem regioner, provinser, land og by samt mennesker er vokset til et punkt, hvor samfundets stabilitet kan trues. Problemet kan tackles og bliver det siden 2004 med "Bæredygtighedspolitikken" et politisk program, der minder om Roosevelts "New Deal"-politik i 1930'ernes USA (Cheng, 2003). For det tredje mangler Kina endnu kapacitet på en række områder: Bogholdere og revisorer, herunder autorisering og selvstændiggørelse af revisionen, skal styrkes for at $\varnothing$ ge transparensen og bogføringsstandarden, men også forskning og udvikling samt logistik og markedsføring er svage områder. I 2005 var Kinas infrastrukturinvesteringer dog ti gange større end Indiens. Dertil kommer, at retssystemet heller ikke er tilstrækkeligt udviklet og selvstændiggjort, fx i forhold til lokal indblanding, til at understøtte globalisering fuldt ud.

For det fjerde kan Kina ikke i længden blive i den lave ende af den internationale arbejdsdeling: Ressourcer og miljø sætter begrænsninger, og der er andre lande med store arbejdskraftreserver. Derfor må man opad i produktionskæden med mere værditilvækst og alt, hvad det indebærer af krav til investeringer i forskning og udvikling, til fremme af videnskab og teknologi og dermed reform af et tungt uddannelsessystem. Vanskelighederne er utallige, men allerede nu er Kina kommet i front på enkelte videnskabelige felter, og flere følger utvivlsomt. Kina leverer allerede flere ingeniør- og naturvidenskabelige kandidater, end Japan, USA eller EU hver gør.

\section{Hvordan kan man karakterisere Kinas statslige globaliseringsstrategi?}

Hvis det er rigtigt, at der er en fundamental ny form for konkurrence mellem stater i det internationale system, nemlig om verdensmarkedsandele, så må staten tilpasse sig dette. "Konkurrencestaten" (Cerny, 1990, 1997) må som følge af den globale konkurrences imperativer udvide sin transnationalisering. National konkurrencedygtighed er det nye kriterium, og politik handler om at skabe betingelser for at øge væksten. Det var dette valg, Deng Xiaoping traf, det tidlige valg af globalisering samtidig med en reduktion af regeringens indblanding i økonomien, men en fastholdelse af dens rolle i visse områder, som skal få produktions- 
faktorerne til at fungere mere effektivt. Kina bidrager med en tredjedel af verdens vækst og vil fortsat $\emptyset$ ge den globale produktivitet, så længe det kan levere dygtig arbejdskraft i et enabling environment skabt af statens store strukturreformer. Men konkurrencestater kan falde forskelligt ud. Den oprindelige udgave var den østasiatiske udviklingsstat, som i takt med integrationen i globale markeder kom til kort i fors $\varnothing g e t$ på at tilrettelægge markedets resultater. Siden har vi set en angloamerikansk model, en japansk model og den europæiske neokorporatistiske udgave (som i øvrigt tiltaler Kina). Konkurrencestaten handler også neomerkantilistisk og underminerer multilateralisme ved sine forsøg på at presse andre stater og transnationale aktører til politikker, der vil ændre balancen i den kompetitive fordel.

Noget tyder på, at Kina reagerer mod den ustabilitet, dette kan forårsage, dels på nationalt, dels på globalt plan. Nationalt synes Kinas strategi at bevare elementer af en Shielder's strategy (Palan og Abbott, 1996: 103), hvor man fors $\emptyset$ ger en selektiv integration i verdens $\varnothing$ konomien i en $\emptyset$ konomisk dualisme, hvor visse sektorer er meget åbne, mens andre, begrundet i fx national sikkerhed eller bevarelsen af national kultur og livsstil, er beskyttede. Investorer tiltrækkes af politisk stabilitet, social harmoni, en produktiv arbejdsstyrke og god infrastruktur. Tabere kompenseres ved velfærdsstatens mekanismer. Denne skræddersyede globalisering bliver svær at fastholde, og Kina studerer nøje de europæiske modifikationer på modellen - samt hvordan man undgår, at policy-kapacitet og politisk autonomi eroderes. I Cernys koncept er den nationale suverænitet mere relativeret, end Kina accepterer, og han peger pessimistisk på en trist udvikling: "A new and potentially undemocratic role is emerging for the state as enforcer of decisions and/or outcomes which emerge from world markets, transnational 'private interest governments', and international quango-like regimes"13 (Cerny, 1997: 258).

På globalt plan bekymrer det Kinas ledelse, at globaliseringen er ustabil, fordi der mangler en form for global governance til at styre den og bringe den gennem kriser. Taler man med kinesiske diplomater i disse år, lægger de en forbløffende, næsten blåøjet, vægt på arbejde med global governance. Det, som måske ikke er så blåøjet, er forventningen om, at der evt. som en følge af globaliseringen samt de regler og institutioner, der kan opbygges omkring den, kan arbejdes hen mod en ny form for stormagtskonkurrence, som er mindre præget af konfliktuelle nulsums-spilopfattelser, og mere af fredelig konkurrence i winwin situationer. Den kan kun sikres ved øget multilateralisme, og det synes i det mindste Kina at have erkendt $\mathrm{i}$ det seneste tiår.

\section{Noter}

1. Det er dog først i 1996, man hører op med at tale om kompleks interdependens, og i 1997, at Jiang Zemin for alvor knæsætter globaliseringen i en tale til partikongressen.

2. Globalisering opfattes som bestående af fire sæt kræfter eller processer: internationalisering; teknologisk revolution; deterritorialisering; liberalisering. Økonomisk globalisering omfatter den intensiverede forbindelse mellem nationale $\varnothing$ konomier sidst $\mathrm{i}$ 
det 20. århundrede, ledsaget af en neoliberal ideologi, som dikterer deregulering og privatisering. Den manifesterer sig som massive bevægelser af produktionsfaktorer, hyperkonkurrence mellem firmaer, nationer og regioner, monetaristisk styring af udbuddet af penge for at begrænse inflation, fremme eksport og tiltrække investering samt pres på nationale regeringer for at deregulere og liberalisere finansmarkeder (Solinger, 2001: 174).

3. Yu redigerede i 2000 Globaliseringens paradoks og i 2002 Globalisering: Vestligg $\phi$ relse eller Sinicering? Han har været gæsteprofessor på fx Duke University og Freies Universität i Berlin.

4. Nomenklaturaen, etpartisystemets mulighed for at godkende besættelsen af ledende stillinger, er fx fortsat et vigtigt redskab til at sikre gennemførelsen af politiske programmer. Den, der hyrer, fyrer og forflytter ledere, kan overvinde en del bureaukratisk modstand.

5. Prakash og Hart opfatter lidt drastisk den økonomiske globalisering som "en større strukturel diskontinuitet i verdensøkonomien." Det nye i forhold til tidligere er ifølge dem de multinationale virksomheders udvidede rolle, med deres intrafirmahandel og de værdikæder, som de har skabt, og som sidst i 1980'erne tegnede sig for en fjerdedel af verdens eksport, og ti år senere en tredjedel. Nøglebeslutninger om ressourceallokering tages stadig mere i firmaet, ikke i markeder eller hos statslige planlægningsmyndigheder.

6. Se Østergaard (2004) for en fremstilling af det kinesiske politiske system og de økonomiske reformer som helhed.

7. En antydning af dette findes i Jiang Zemins overvejelser ("der er ikke længere nogen mulighed for at unddrage sig globaliseringen af økonomi, videnskab og teknologi ... hvis Kina ikke skal gå glip af globalt medborgerskab") i den politiske rapport til KKP's 15. Kongres i 1997. Denne rapport genoptager ideer fra en kort debat i 1988 om "globalt medborgerskab", at Kina i en globaliseringsæra kan vælge ikke at emancipere sin politisk-økonomiske tænkning og dermed falde tilbage i teknologikapløbet samt miste sit globale medborgerskab, eller kan integrere sig fuldt ud, gøre kreativt brug af verdensmarkedet og dermed komme i de forreste rækker som en verdensmagt (Kim, 2000: 12).

8. Denne analyse bygger på et utal af især kinesiske artikler og analyser, som pladsforholdene ikke gør det muligt at anføre.

9. Der oprettes fire $\varnothing$ konomiske zoner i 1981, senere kommer 14 kystbyer til med særlige privilegier. Det kan være fritagelse for importtold, hel eller delvis fritagelse for indkomstskat i fem år, loft på 15 pct. skat - og endnu mindre, hvis det er højteknologisk eller eksportorienteret produktion eller helt skattefrit, hvis man reinvesterer overskuddet i Kina.

10. Diasporapolitikken over for de 50 millioner, ofte meget formuende og investeringslystne, kinesere i udlandet er således også en globaliseringsstrategi.

11. Breslin (2004) ser det som "et økonomisk system, hvor staten skaber det rum, den private sektor kan dominere, og regulerer markedet, så det nye bourgeoisie kan tilegne sig merværdi takket være sin nære forbindelse med partistaten: 'kapitalisme med kinesiske særtræk"”.

12. Der er fortsat nogle muligheder, dels ved statsledede fusioner, dels ved at støtte de stærkeste ikke-statsejede som fx Haier, verdens største hvidevareproducent, dels at staten bliver bedre til at støtte forskningen og den teknologiske opgradering. I 2004 gav regeringen fornyet opbakning til dette (Zhang, 2005: 14).

13. Quango = quasi-autonom nongovernmental organisation, et organ med myndighed, med licens fra staten til at udføre offentlige regulerende funktioner, men bestående af udpegede repræsentanter for privatsektorinteresser. 


\section{Litteratur}

Ahya, Chetan et al. (2006). India and China: New Tigers of Asia, pt. II, Hong Kong: Morgan Stanley.

Breslin, Shaun (2004). "Capitalism with Chinese Characteristics: the Public, the Private and the International", Working Paper no. 104, Murdoch University: Asia Research Centre.

Cai, Kevin (2004). "Chinese changing perspective on the development of an East Asian Free Trade Area", Review of International Affairs, Vol. 3, No. 4, pp. 584-599.

Cerny, Philip (1990). The changing architecture of politics. Structure, Agency and the Future of the State, London: Sage.

Cerny, Philip (1997). "Paradoxes of the Competition State: the dynamics of political globalization", Government and Opposition, Vol. 32, No. 1, pp. 251-274.

Cheng, Li (2003). "The 'New Deal': Politics and Policies of the Hu Administration", Journal of African and Asian Studies, Vol. 38, No. 4-5, pp. 329-346.

Cox, Robert (1996). Approaches to World Order, Cambridge: Cambridge University Press. Fingar, Thomas (1980). "Beijing's foreign trade debate in 1975", in Thomas Fingar (ed.), China's Quest for Independence: Policy Evolution in the 1970s, Boulder: Westview Press.

Fung, Gay-hung and Kevin H. Zhang (eds.) (2002). Financial markets and foreign direct investment in Greater China, London: M.E. Sharpe.

Garrett, Banning (2001). "China faces, debates, the contradictions of globalisation", Asian Survey, Vol. 41, No. 3, pp. 409-427.

Gentelle, Pierre (1999). Chine et "Chinois" outre-mer a l'oree du XXIe siecle, Paris: SEDES.

Howell, Jude (1993). China, opens its doors, Hemel Hempstead: Harvester.

$\mathrm{Hu}$, Angang (2001). Chinas integration into the world economy, Beijing: Center for China Study.

Jacques, Martin (2006). "Globalization has had its day", Guardian Weekly, 21-27.07, p. 27.

Jiang, Xiaojuan (2005). "Prospects and Analysis of FDI in China", China \& World Economy, Vol. 13, No. 4, pp. 34-43.

Johnston, Alistair (2003). "Is China a Status Quo Power?", International Security, Vol. 27, No. 4, pp. 5-56.

Kennedy, Scott (2005). The business of lobbying in China, Cambridge: Harvard University Press.

Kim, Samuel (2000). Korea's globalization, Cambridge: Cambridge University Press.

Lampton, David (ed.) (2001). The Making of Chinese Foreign and Security Policy in the Era of Reform 1978-2000, Stanford: Stanford University Press.

Liew, Leong (2005). "China's Engagement with Neo-Liberalism: Path Dependency, Geography and Party Self-Reinvention", Journal of Development Studies, Vol. 41, No. 2, pp. 331-352.

Lu, Ding et al. (2003). China's Economic globalization through the WTO, Aldershot: Ashgate.

Moore, Thomas (2002). China in the world market, Cambridge: Cambridge University Press.

Moore, Thomas (2005). "Chinese Foreign Policy in the Age of Globalisation", pp. 121158 in Yong Deng and Fei-ling Wang (eds.), China Rising. Power and Motivation in Chinese Foreign Policy, Lanham: Rowman and Littlefield.

Nolan, Peter (2001). China and the Global Economy, London: Palgrave.

Palan, Ronen and Jason Abbott (eds.) (1996). State strategies in the global political economy, New York: Pinter.

Prakash, Aseem and Jeffrey A. Hart (eds.) (2000a). Coping with Globalization, London: Routledge. 
Prakash, Aseem and Jeffrey Hart (eds.) (2000b). Responding to Globalization, London: Routledge.

Qin, Xiaoying (2006). "Competitiveness just one part of economic jigsaw", China Daily, 23.05 , p. 4.

Ramo, Joshua Cooper (2004). The Beijing Consensus, London: The Foreign Policy Centre.

Solinger, Dorothy (2001). "Globalization and the paradox of participation: The Chinese Case", Global Governance, Vol. 7, No. 2, pp. 173-196.

Strange, Gerard (2003). "Beyond 'third wave' globalisation analysis: a critical review of structural dependency theory in IPE", European Political Science, Vol. 2, No. 2, pp. $1-9$.

Wan, Guanghua, Lu Ming and Zhao Chen (2004). Globalization and regional income inequality. Evidence from within China, Helsinki: UNU-WIDER.

Wong, John (2006). "China's Economy in 2005: At a new turning point and need to fix its development problems", China \& World Economy, Vol. 14, No. 2, pp. 1-15.

WSJ (2006). "Lobbyists Target China Legislators. Changes mark a rise in interest groups amid societal shifts", 09.03, p. A4.

Yang, Dali L. (2004). Remaking the Chinese Leviathan. Market Transition and the Politics of Governance, Stanford: Stanford University Press.

Yang, Dali L. and Fubing Su (2000). "Taming the market: China and the forces of Globalization”, pp. 33-64 in Aseem Prakash and Jeffrey Hart (eds.), Responding to Globalization, London: Routledge.

Yu, Keping (2004). "From the discourse of 'Sino-West' to globalization: Chinese perspectives on globalisation", GHC Working Paper 04/1, McMaster University: Working Paper Series.

Zhang, Yongjin (2005). China Goes Global, London: The Foreign Policy Centre.

Zhang, Yunling (2004). East Asian Cooperation. Searching for an integrated approach, Beijing: World Affairs Press.

Zheng, Yongnian (2004). Globalization and state transformation in China, Cambridge: Cambridge University Press.

Zweig, David (2002). Internationalizing China: Domestic interests and global linkages, Ithaca: Cornell University Press.

Østergaard, Clemens S. (1995). "Economic transformation in China. The role of State vs Market", pp.183-202 in Laurids L. Lauridsen (ed.), Institutions and Industrial Development: Asian Experiences, Roskilde: International Development Studies.

Østergaard, Clemens S. (2004). Kinas eksperimenter. Reformer og stormagtsstatus?, København: Columbus. 